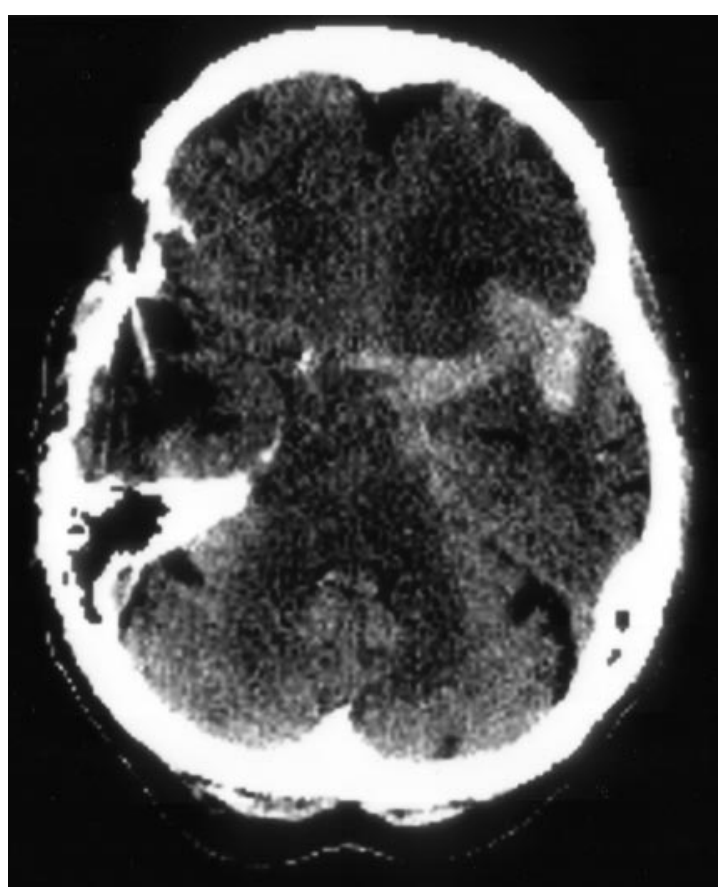

Figure 1. Bloody arrow in the left sylvian fissure.

\section{Arrow sign in MCA trifurcation aneurysm}

Boby Varkey Maramattom, MD, DM; and Eelco F.M. Wijdicks, MD, Rochester, MN

An 80-year-old woman had a thunderclap headache. CT scan revealed blood in the left sylvian fissure. The clot took the form of

Address correspondence and reprint requests to Dr. Boby Varkey, Flat 18, Kairali Apartments, Panampally Nagar, Kochi, Ke, India; e-mail: Maramattom.Boby@mayo.edu
Neurolmages

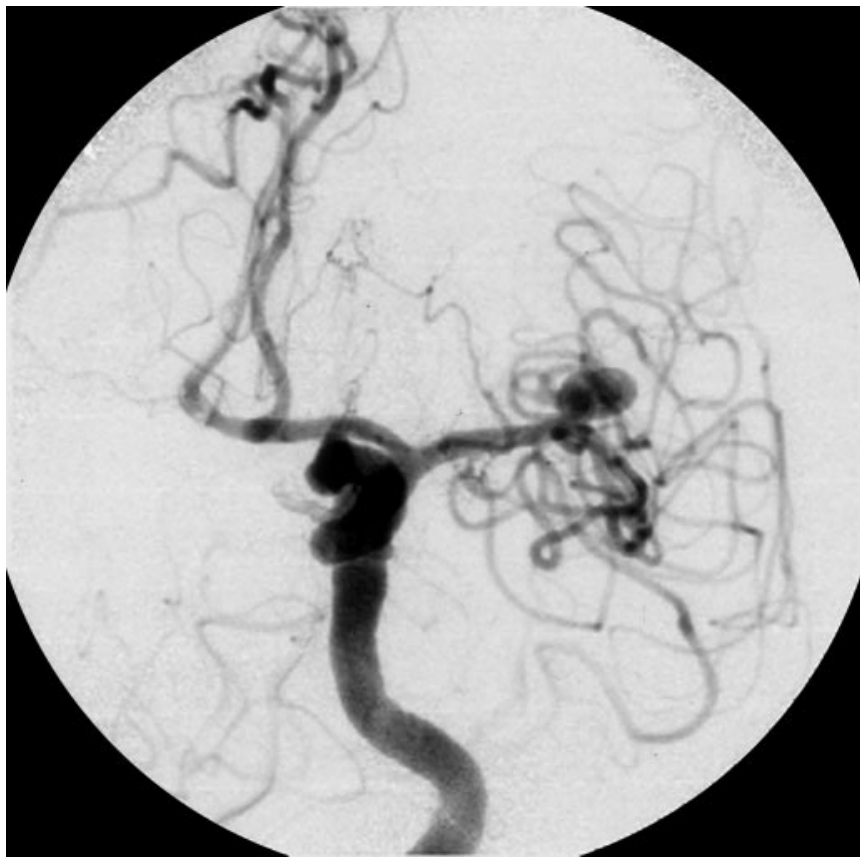

Figure 2. Four-vessel DSA shows a left MCA trifurcation aneurysm.

an arrow (figure 1). Four-vessel digital subtraction angiography (DSA) showed a $7 \mathrm{~mm}$ left middle cerebral artery (MCA) trifurcation aneurysm (figure 2). The aneurysm was subsequently coiled.

The pattern of blood in the subarachnoid space on CT scan could indicate the location of the underlying aneurysm. In MCA aneurysms, hemorrhage predominates in the sylvian fissure. In this patient the arrow configuration was formed by seepage of blood between the insula and the frontal and temporal opercula of the sylvian cistern near the MCA trifurcation. ${ }^{1}$

1. Rhoton AL Jr. The cerebrum. Neurosurgery 2002;51(4 suppl):S1-51. 


\title{
Neurology
}

\author{
Arrow sign in MCA trifurcation aneurysm \\ Boby Varkey Maramattom and Eelco F.M. Wijdicks \\ Neurology 2004;63;1323 \\ DOI 10.1212/01.WNL.0000141953.58554.D9
}

This information is current as of October 11, 2004

\section{Updated Information \& Services}

References

Subspecialty Collections

Permissions \& Licensing

Reprints including high resolution figures, can be found at: http://n.neurology.org/content/63/7/1323.full

This article cites 1 articles, 0 of which you can access for free at: http://n.neurology.org/content/63/7/1323.full\#ref-list-1

This article, along with others on similar topics, appears in the following collection(s):

\section{All Cerebrovascular disease/Stroke}

http://n.neurology.org/cgi/collection/all_cerebrovascular_disease_strok e

CT

http://n.neurology.org/cgi/collection/ct

Subarachnoid hemorrhage

http://n.neurology.org/cgi/collection/subarachnoid_hemorrhage

Information about reproducing this article in parts (figures,tables) or in its entirety can be found online at:

http://www.neurology.org/about/about_the_journal\#permissions

Information about ordering reprints can be found online:

http://n.neurology.org/subscribers/advertise

Neurology ${ }^{\circledR}$ is the official journal of the American Academy of Neurology. Published continuously since 1951, it is now a weekly with 48 issues per year. Copyright . All rights reserved. Print ISSN: 0028-3878. Online ISSN: 1526-632X.

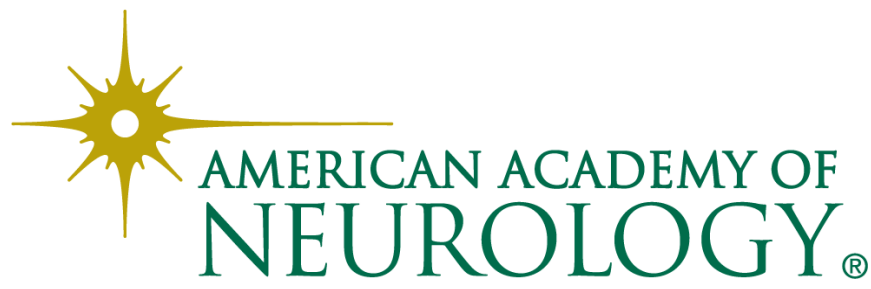

